\title{
A Methodology for Measuring the Sustainability of Car Transport Systems
}

\author{
T.W. Smith ${ }^{\mathrm{a}}$, C.J. Axon ${ }^{\mathrm{b}}$ and R.C. Darton ${ }^{\mathrm{a} *}$. \\ ${ }^{a}$ Department of Engineering Science, University of Oxford, Oxford, OX1 3PJ, UK. \\ ${ }^{\mathrm{b}}$ School of Engineering and Design, Brunel University, Uxbridge, London, UB8 3PH, UK. \\ Colin.Axon@brunel.ac.uk +44 1895267932 \\ * Corresponding author: Richard.Darton@eng.ox.ac.uk +44 1865273188
}

\begin{abstract}
Measuring the sustainability of car fleets, an important task in developing transport policy, can be accomplished with an appropriate set of indicators. We applied the Process Analysis Method of sustainability assessment to generate an indicator set in a systematic and transparent way, that is consistent with a declared definition of a sustainable transport system. Our method identifies stakeholder groups, the full range of impacts across the environmental, economic and human / social domains of sustainability, and those who generate and receive those impacts. Car users are shown by the analysis to have dual roles, both as individual makers of decisions and as beneficiaries / sufferers of the impacts resulting from communal choice. Thus car users, through their experience of service quality, are a potential force for system change. Our method addresses many of the well-known flaws in measuring transport sustainability. The indicator set created is independent of national characteristics and will be useful to transport policy practitioners and sustainable mobility researchers globally.
\end{abstract}

Keywords: Car fleet, Indicator, Mobility, Process Analysis Method, Sustainability, Transportation.

\section{Introduction}

Over a period of one hundred years the motor car has come to occupy a central role in all developed economies. It has transformed our ability to travel easily and cheaply for work or leisure purposes, and it has changed the design of our urban spaces. Since 1913 the UK car fleet ${ }^{1}$, for example, has grown from a negligible size to nearly 30 million units, and the vehicle-kilometers driven are now approaching 460 billion annually (DfT, 2012). The benefits of increasing personal mobility nevertheless come at the cost of negative impacts, some of which are well known (accidents, pollution), though others are not widely recognised. In view of the importance of motor car transport, it is perhaps surprising that more work has not been done to monitor its overall impact despite the availability of much statistical data that would support a regular comprehensive assessment. Studies which focus solely on benefits or on problems, neither give a fair picture nor illuminate the difficult balance in preserving the freedom of near-ubiquitous mobility whilst mitigating the various disbenefits. Making that comprehensive assessment is the role of a sustainability analysis.

Measuringing the sustainability of a car fleet requires an objective framework. Such a multicomponent complex system can only be characterised by carefully chosen indicators which capture the interactions within the system as a whole. A number of studies in the literature describe indicator sets for sustainable transport but the selection of indicators remains difficult, either due to a lack of clear goals (such as, what is a sustainable outcome for a transport system?) or to the lack of a systematic process. Many studies perform numerical analyses for indexing, ranking and benchmarking purposes, selecting from indicators found in the literature (Shiau and Jhang, 2010, Hagshenas and Vaziri, 2012; Bojkovic et al., 2010; Yigitcanlar and Dur, 2010). This approach, whilst pragmatic, does not give us confidence either that the indicator set will be complete, or represent a defined view of sustainability. Miranda and Rodrigues da Silva (2012) offer an alternative approach, using extensive stakeholder consultation to generate the indicators; whilst this ensures relevance and transparency, it is susceptible to bias in terms of the stakeholders chosen to participate. Several authors emphasize the importance of understanding what a sustainable transport system entails (Black, 2002; Marsden et al., 2010; Too and Earl, 2010; Henning et al., 2011; Jeon et al., 2013). Amongst these, Henning et al. draw on national transport policy to guide indicator selection, and Jeon et al.

\footnotetext{
${ }^{1}$ The car fleet in the UK is defined as vehicles belonging to the 'private and light goods' tax class.
} 
Final version appeared as: TW. Smith, CJ. Axon, \& RC. Darton (2013). A Methodology for Measuring the Sustainability of Car Transport Systems. Transport Policy, 30, pp. 308-317, DOI:10.1016/ j.tranpol.2013.09.019.

derive indicators based both on sustainability issues and the goals of regional transport policy. Ramani et al. (2011) conducted interviews with selected US and international transportation agencies to identify suitable elements for a framework to be used by such agencies to promote sustainable transportation. Castillo and Pitfield (2010) present a method for ranking and selecting transport indicators found in the literature, linking the indicators to top level goals and assessing them in terms of clearly stated criteria. However, they do not address the issue of how to generate the indicators in the first place. Several studies present seemingly complete, comprehensive indicator sets but lack a clear framework or method by which the indicators were generated, which means that it is difficult to check that all the impacts have been captured (Kennedy, 2002; Walker et al., 2006; WBCSD, 2004; Nicolas et al., 2003; Journard and Nicolas, 2010; Fedra, 2011). Using indicators as a tool for driving change by focusing on just a few, such as $\mathrm{CO}_{2}$ emissions, provides an incomplete picture of the issues (Roth and Kåberger, 2002; Grimes-Casey et al., 2009; Zachariadis, 2005).

Chee Tahir and Darton (2010) present a method for generating indicators to describe the sustainability of a business, called the Process Analysis Method (PAM). Whilst it was developed for the assessment of a manufacturing business, the method addresses many of the weaknesses identified above. It has a clear framework that ensures both relevance and completeness and that links the indicators to top-level goals. This method thus follows the suggestion of Dalal-Clayton and Bass (2007) that a well-designed indicator framework be systemic, hierarchical, logical and communicable.

It is clear that the indicator set should reflect the stated goals of the analysis. In our study we aimed to quantify the sustainability performance of the UK car fleet as it changed over a recent ten-year period. The indicator set is therefore intended to measure the sustainability performance of the car fleet as an entity. We aim to give a full picture of the car fleet, which is a major provider of personal mobility in the UK. We do not consider other transportation options, nor how policy could be framed to provide mobility in a different way, nor how society's need for mobility might be reduced. Our analysis of the car fleet does reveal aspects of good and poor performance which are relevant for policy formulation.

\section{Applying the PAM to Transport}

The Process Analysis Method (PAM) consists of a series of steps that formalise the process of generating sustainability indicators for a specific system. The fundamental proposition of the methodology is that impacts are the result of processes occurring within the system (Chee Tahir and Darton, 2010). The first step involves breaking the system down into individual processes, choosing a definition of sustainability and setting a system boundary. Each process within the boundary is then evaluated in terms of its impact on the three sustainability domains: environmental, economic and social, the "triple bottom line" approach introduced by Elkington (1998). Each domain represents a store of value which can be affected by this impact, either to enhance, diminish or leave unchanged the quantity or quality of the capital. Impacts cause one or more issues, which affect one or more stakeholders, known as external impact receivers (EIR). Issues are consequences of these impacts: for example, Primary energy resource depletion (impact) results in Fewer available resources to meet future needs (issue); Mobility is provided (impact) results in People are able to travel (issue). Indicators are then selected to describe these issues. Figure 1 illustrates how the different steps in the method relate to each other. The definition of sustainability is used to ascertain which impacts are causing sustainability issues for particular stakeholders (either positive or negative), which provides a means of checking whether a particular impact is relevant. Since the issues are checked against the definition of sustainability, the method should produce consistent results for a given definition. Furthermore, each indicator is linked to a specific issue, affecting a specific stakeholder group, and each issue is linked to a specific impact. In this way PAM produces transparent results, as indicators can be linked back to a specific system process.

As a case study, we apply the PAM to the UK car fleet to generate a set of sustainability indicators for car-based transportation. Since the methodology was originally designed as a means of assessing the sustainability performance of a manufacturing business, applying it to a decentralised, service-based system such as the car fleet presented a new challenge. 
Final version appeared as: TW. Smith, CJ. Axon, \& RC. Darton (2013). A Methodology for Measuring the Sustainability of Car Transport Systems. Transport Policy, 30, pp. 308-317, DOI:10.1016/ j.tranpol.2013.09.019.

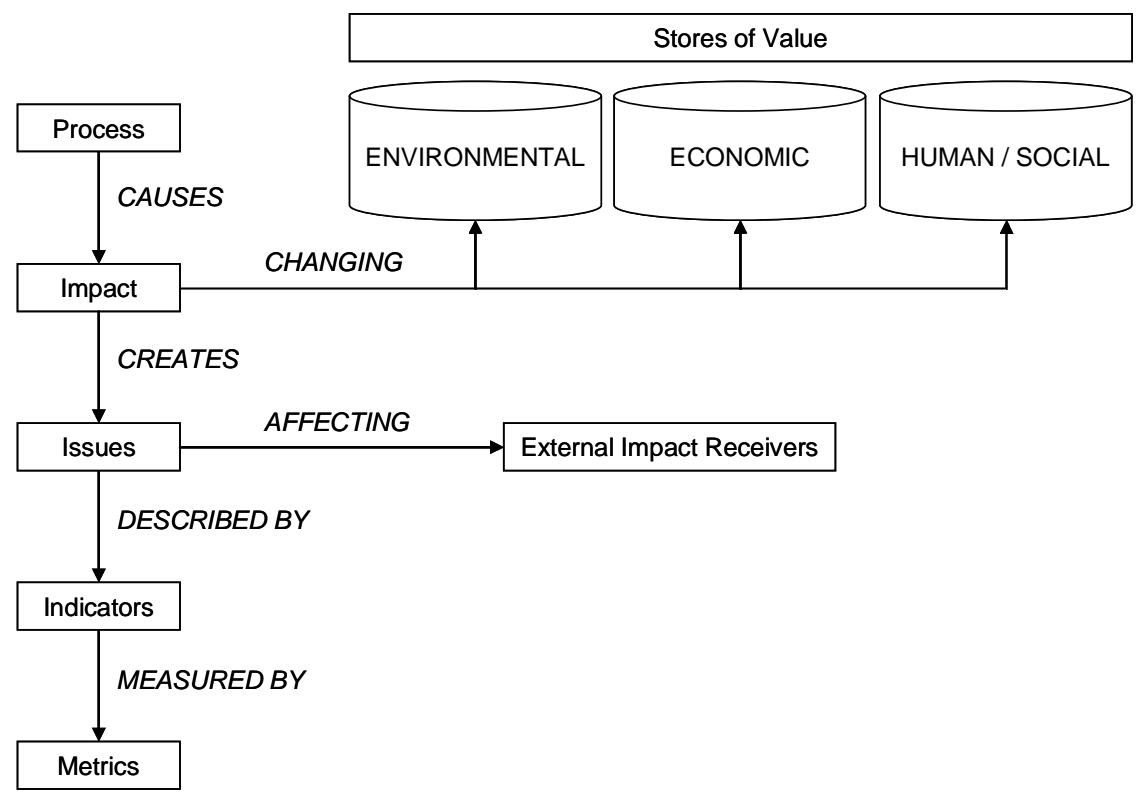

Figure 1. The Process Analysis Method.

\subsection{Overview of the System}

The first step is to construct a comprehensive overview of the system to identify the major processes and the associated input/output and stakeholder interests. The main processes, shown in Figure 2, loosely describe the car life-cycle. Generally speaking, the impact of a process can be linked either to the resources used (inputs) or to the resulting products and waste (outputs). We considered the resources in five categories: energy, materials, land, water and workforce. Once the analysis is complete, the system can be reduced to a single, top-level process which provides mobility, with the inputs as the sum of all resources used, and the outputs as mobility and a variety of wastes. The outcome, shown in Figure 3, is analogous to a heat engine: the transport system (engine) is fuelled by resources and produces both mobility, the desirable output and waste (degraded or less valuable resource). The inputs and outputs have impacts on the three stores of value.

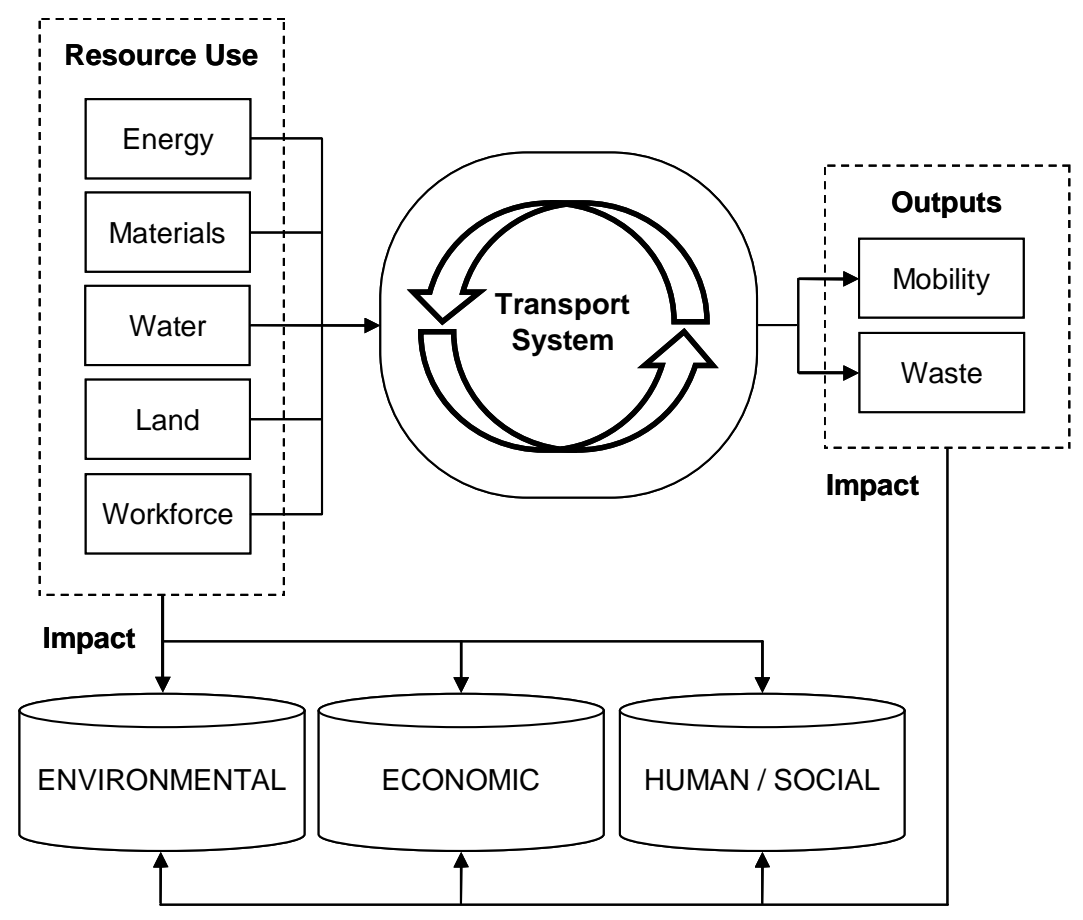

Figure 2. Processes identified in system overview. 
Final version appeared as: TW. Smith, CJ. Axon, \& RC. Darton (2013). A Methodology for Measuring the Sustainability of Car Transport Systems. Transport Policy, 30, pp. 308-317, DOI:10.1016/ j.tranpol.2013.09.019.

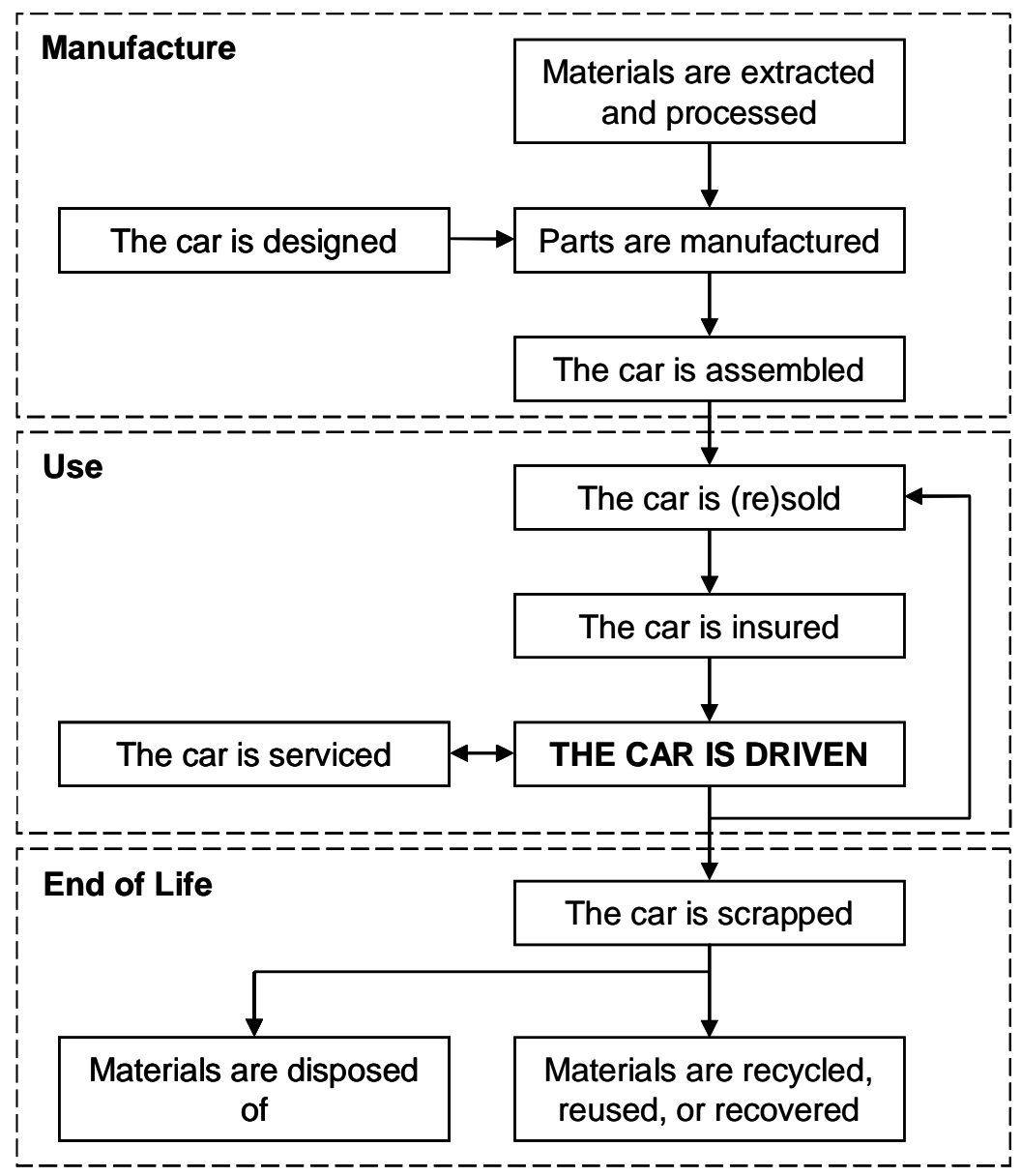

Figure 3. Top-level view of analysis.

\subsection{Working Definition of Sustainability}

The working definition of sustainability informs the criteria by which the system will be evaluated. It helps to tie impacts to specific issues by highlighting the requirements for a sustainable system. The definition must therefore be precise and clearly state what a sustainable outcome entails.

The literature reports definitions of transport sustainability which provide useful insights, but are not precise in stating what constitutes a sustainable outcome (European Commission, 2001). Akinyemi's (2002) definition is interesting as it recognises the role of a transport system, explicitly identifying the level of service provided as a criterion for sustainability. Many papers take the Brundtland (1987) definition of sustainable development as a starting point (Richardson, 2005; Rassafi, 2005; Roth and Kåberger, 2002) and apply it in different ways, but the Brundtland definition is very general - to be useful, further analysis of how a transport system meets current needs and affects future generations is required.

Our definition is the result of such analysis. The provision of mobility has a direct effect on meeting current needs (the need to travel), but the system also causes environmental and social impacts, including resource depletion; these impacts affect both present and future generations. We include the rules of Rennings and Wiggering (1997) to address the use of stock-dependent or non-renewable resources. A further distinction is made, distinguishing between recoverable and non-recoverable stock-dependent resources. Recoverable refers mainly to abiotic resources such as steel, which can be recovered for further use. Nonrecoverable refers to resources such as fossil fuels or most plastics that are degraded to an extent that prevents their re-use or recycle. We thus define a sustainable transport system as one which:

1. delivers for all socioeconomic groups and at any given time, levels of mobility and safety of movement that society considers to be ideal,

2. consumes or requires at any given time, rate-dependent resources that are not greater than the resources that can be internally generated,

3. consumes non-recoverable stock-dependent resources in a quasi-sustainable manner by limiting their rate of depletion to the rate of creation or development of rate-dependent substitutes, 
Final version appeared as: TW. Smith, CJ. Axon, \& RC. Darton (2013). A Methodology for Measuring the Sustainability of Car Transport Systems. Transport Policy, 30, pp. 308-317, DOI:10.1016/ j.tranpol.2013.09.019.

4. recycles recoverable stock-dependent resources,

5. does not systematically create environmental impacts that degrade the natural environment,

6. in its provision of mobility, maximises positive impacts on society (e.g. employment), whilst minimising undesirable human / social impacts (e.g. negative health effects).

This definition echoes the Brundtland definition in considering the needs of the present (e.g. mobility, employment) whilst safeguarding future generations against undesirable impacts. The first clause addresses the role of the system, whilst clauses 2, 3 and 4 aim to ensure zero resource depletion by regulating resource consumption to sustainable levels. In a sustainable system, all recoverable materials should be recycled or re-used. Note that clause 2 also applies to monetary resources and thus requires that the system remains economically viable. Clauses 5 and 6 protect the natural and human / social stores of value from undesirable impacts.

A difficulty commonly encountered in describing the sustainability of a specific system is that of deciding what constitutes acceptable levels of resource use and environmental impact relative to other systems. For example, how much of a society's acceptable carbon dioxide production (meaning within the environmental capacity) should be allocated to transport? Another difficulty is how to balance improvements in one area against deterioration in another, for example, a decrease in emissions against an increase in vehicle cost. These are societal issues - the balance reflects societal priorities. Our method exposes such tensions, but does not resolve them. Chee Tahir and Darton (2010) derive two business perspectives from the Brundtland definition which provide a basis on which to assess impacts and generate indicators that will push the system towards sustainability. These perspectives are:

Resource efficiency [which] measures how effectively the capital is used or created (change can occur in both the amount of capital and its quality); and

Fairness in (dis)benefit [which] means, with regard to using or changing the capital, both (a) how fairly benefits are distributed, and (b) how fairly disbenefits are distributed.

These perspectives are not criteria for sustainability; they indicate the desired direction of travel, and by maximizing them the system will tend to become more sustainable.

\subsection{Define the System Boundaries}

The spatial boundary determines what processes should be included in the analysis, whilst the temporal boundary defines the period over which impacts are considered. In this study, the system under consideration is the UK car fleet and the processes that support it. The boundaries are chosen to be in line with the goal of the study: to measure the impact that the system is having on the sustainable development of our society and the sustainability of our environment.

The spatial boundary is the geographical boundary of the UK. We include impacts related to the manufacture, sale, operation, insurance, maintenance and disposal of cars in the UK. However, some processes, such as manufacture, involve long supply chains which reach well beyond this boundary. Ignoring the impact of these supply chains could misrepresent the overall sustainability of the system. Pragmatically a line does need to be drawn - and we chose to include data on impacts occurring outside this boundary when these were significant relative to those occurring within. We thus included the embodied energy and emissions of imports to the UK of vehicles, materials for vehicle manufacture and fuels for use in vehicles. Supporting infrastructure such as roads and refuelling stations was excluded from the study because it also serves a variety of non-car related activity.

The temporal boundary is formed by the two study years, 1995 and 2005. This ten-year interval encompasses changes in patterns of use, regulation and technology allowing us to demonstrate - with reported data - how the PAM can be used to track car fleet sustainability. In particular, increasingly stringent European emissions standards began to take effect: EURO 2 came into force in 1996, EURO 3 in 2000 and EURO 4 in 2005. Prior to 1995 many sources of data are less extensive and robust. However, certain impacts (such as global warming, other health effects) create issues beyond this period. In such cases, provided the impact originated during the study years, the boundary is extended to 100 years later.

The scope of the study also creates certain boundaries. In this analysis, no attempt is made to place a value on the benefits (or disbenefits) of the purpose attributed to the trips performed by users of the car fleet. Mobility is considered to be a positive benefit, regardless of whether it is used for shopping, work or anything else. This analysis is concerned with how efficiently mobility is produced by the motor car fleet, 
Final version appeared as: TW. Smith, CJ. Axon, \& RC. Darton (2013). A Methodology for Measuring the Sustainability of Car Transport Systems. Transport Policy, 30, pp. 308-317, DOI:10.1016/ j.tranpol.2013.09.019.

how well it is provided and how equitably it is made available to society; that is, how well it meets the needs of society. We do not consider whether the mobility needs of society could be better met in a different way (e.g. by better urban planning). As a consequence, impacts such as the benefit of better transport links are not included. If better transport links were created the benefit would be reflected in our methodology only by an increase in the quality and/or quantity of the resulting mobility, or in the efficiency of its provision.

\subsection{Identify the Internal Impact Generators}

The Internal Impact Generators (IIGs) are the decisions taken, or policies implemented by stakeholders within the system that give rise to processes which cause impacts on the stores of value. For the car fleet, four IIGs were identified:

User decisions: Users exert an influence through the choices they make, in terms of mode, amount of travel, type of vehicle purchased/rented, driving style etc. Users are also impact receivers - they are affected by the consequences of their own resource use (although many of these consequences are not solely borne by them). There is therefore an element of feedback in the system, as users modify their decisions according to the consequences of previous choices. Users value the various attributes of a transportation system according their own tastes and the activity they intend to perform at their destination. The users are not a homogenous group or entity, and the impact they have is an emergent property of a series of individual choices. This affects the way they react to feedback.

Government policy and regulation: These include manufacturing standards (e.g. emissions standards), management of the car fleet through vehicle licensing and MOT $^{2}$, management of the road network and taxation of fuel and cars and related services, as well as standards and legislation applied to disposal. Other and more general elements of government policy, for example on health and safety, or energy efficiency will also be relevant.

Car manufacturer design, research and development choices. Whilst it may at first appear that the car manufacturers are purely impact receivers since they respond to consumer demand and government regulation, they do play a key role in choosing what technologies to research, develop and implement in their products. Technology choice has a crucial impact on the system constraints, as it greatly influences resource use and wastes and service quality.

Car manufacturer sustainability policy and practices. Although sustainability policy could also be considered a response to consumer demand and government regulation, the extent of car manufacturer's commitment to environmentally and socially sustainable practices will also influence the impacts of the processes of car production and operation.

\subsection{Identify the External Impact Receivers}

The actions of the IIGs change the stores of value, which affects the owners or guardians of the capital stakeholders called External Impact Receivers (EIRs). Their concerns regarding a particular impact constitute 'issues'. We identified five EIRs for this study:

Communities represent the collective sum of people that form human societies, in this case the UK population. They are affected by a range of impacts, including those that affect the environment in so far as this leads to an impact on human societies, for instance in terms of health effects. Community interests are often represented by other groups such as government or NGOs.

Future communities are the communities that will exist in the future. They are broadly affected by the same issues as communities, only over a longer time frame. They are also affected by resource depletion. Again, these are often represented by government and NGOs, acting on their behalf.

Users are the users of the UK car fleet, passengers and drivers. They are mainly affected by service quality, but also by cost. Users are a subset of communities, and are affected by all community impacts as well as user specific impacts.

Employees are people employed in the motor industry and associated services. They are also a subset of communities, but are affected by virtue of their employment.

Capital providers represent the collective group of investors who benefit directly from the profitability of the motor industry and associated services in the UK.

\footnotetext{
${ }^{2}$ In the UK the "MOT" is a certificate of roadworthiness that the owner must obtain following a test when the car is older than three years. It ensures a minimum standard.
} 
Final version appeared as: TW. Smith, CJ. Axon, \& RC. Darton (2013). A Methodology for Measuring the Sustainability of Car Transport Systems. Transport Policy, 30, pp. 308-317, DOI:10.1016/ j.tranpol.2013.09.019.

There is overlap between EIRs, since certain individuals may feature as members of more than one EIR, which is not unusual with the PAM. The important point about the identification of EIRs is that it introduces into the method the people who are affected by the impacts. Their views, obtained perhaps by stakeholder consultation, help to ensure that the full range of issues arising from the impacts are taken into account. The overlap does not influence the analysis, which recognises that overlapping groups may hold different views. For example, users may wish more for high speeds and short journey times, whilst communities may be fearful of the environmental and health consequences of high speeds.

\subsection{Identify the Indicators and Metrics}

Indicators are selected to describe the issues, and metrics are developed for each indicator. The metric measures the severity of the impact caused by the IIGs on each store of value - environmental, economic or social. Specification of the metrics is the last step in analyzing the logical chain illustrated in Figure 1: process causes impact creates issues described by indicators measured by metrics.

\section{Indicator Set}

The indicators generated by the application of the PAM were used to measure the sustainability of the UK car fleet in the two years 1995 and 2005. This case study was designed to show the way in which sustainability changed between these years. Examples are given to illustrate the methodology.

\subsection{Environmental Indicators}

The processes of manufacture, operation and disposal of the car fleet all impact the environmental store of value. Environmental issues fall into two main categories: damage caused by waste (emissions to air, water and ground), and the depletion of natural resources. Table 1 shows the selected indicators. There is a rich literature from which to draw information on these types of environmental impacts, and the Life Cycle Assessment literature provides detailed lists of pollutants and their respective impacts, including weighting factors based on their potency (Baumann and Tillmann, 2004; IChemE, 2004; Guinée et al., 2002; AEA, 2010). Natural resource depletion affects future communities - although the resource needs of future communities are uncertain, current trends suggest that energy, materials, water and land will be in even greater demand.

The primary energy resource depletion indicator is chosen to illustrate the application of the indicator set in the case study. Changes in this indicator are the result of several IIGs. For example, fuel efficiency improved as a result of better engine design (IIG is Car manufacturer design, research and development choices) promoted by vehicle excise duty policy (IIG is Government policy and regulation); as a result, primary fuel energy consumption increased by $4.4 \%$, much less than the increase in kilometres travelled (16.2\%). Table 2 shows that the total primary energy metric increased by $9.3 \%$ between the two study years. Three main areas of energy consumption were identified: fuel used to operate the fleet, energy embodied in the manufacture of new vehicles added to the fleet and energy embodied in the production of fuel. To calculate the energy and emissions due to manufacture, we adapted the GREET $^{3}$ model to reflect the typical UK car during each study year. Fuel energy consumption was taken from DFT (2007), and embodied energy and emissions due to fuel production were calculated using data from Edwards et al. (2007).

Other trends also contributed to the results presented in Table 2. There was a sharp increase in the number of vehicles, shown by an increase of $28.6 \%$ in annual new registrations and of $28.7 \%$ in total registrations. The average weight of a new vehicle increased; the European Automobile Manufacturers Association suggests an increase of approximately 14.5\% between 1995 and 2004 (European Commission, 2006). This, together with the increased registrations, explains the change in embodied energy in new vehicles.

\footnotetext{
${ }^{3}$ Greenhouse Gases, Regulated Emissions, and Energy Use in Transportation (GREET) Model, Argonne National Laboratory, USA, http://greet.es.anl.gov/
} 
Final version appeared as: TW. Smith, CJ. Axon, \& RC. Darton (2013). A Methodology for Measuring the Sustainability of Car Transport Systems. Transport Policy, 30, pp. 308-317, DOI:10.1016/ j.tranpol.2013.09.019.

Table 1. Environmental indicators of car transport system sustainability.

\begin{tabular}{|c|c|c|c|c|c|}
\hline $\begin{array}{l}\text { Input / } \\
\text { Output }\end{array}$ & Impact & Issue & EIR & Indicator & Metric \\
\hline \multirow[t]{8}{*}{ Energy } & Acidification & $\begin{array}{l}\text { Increasing acidity in } \\
\text { soil, lakes and rivers }\end{array}$ & Communities & $\begin{array}{l}\text { Emissions of pollutants } \\
\text { characterised in Guinée et al. } \\
(2002)\end{array}$ & $\begin{array}{l}\mathrm{t}^{-1} \mathrm{SO}_{2} \\
\text { equivalent }\end{array}$ \\
\hline & Eutrophication & Ecosystem degradation & Communities & See above & $\begin{array}{l}\mathrm{t}^{-1} \mathrm{PO} 4 \\
\text { equivalent }\end{array}$ \\
\hline & $\begin{array}{l}\text { Global } \\
\text { Warming }\end{array}$ & $\begin{array}{l}\text { Stores heat, causing } \\
\text { global warming }\end{array}$ & $\begin{array}{l}\text { Future } \\
\text { communities }\end{array}$ & See above & $\begin{array}{l}\mathrm{t}^{-1} \mathrm{CO} 2 \\
\text { equivalent }\end{array}$ \\
\hline & $\begin{array}{l}\text { Photochemical } \\
\text { Oxidation }\end{array}$ & $\begin{array}{l}\text { Ozone causes irritation } \\
\text { to respiratory systems } \\
\text { and can damage } \\
\text { vegetation and materials }\end{array}$ & Communities & See above & $\begin{array}{l}\mathrm{t} \mathrm{y}^{-1} \\
\text { ethylene } \\
\text { equivalent }\end{array}$ \\
\hline & $\begin{array}{l}\text { Ozone Layer } \\
\text { Depletion }\end{array}$ & $\begin{array}{l}\text { Depletion of } \\
\text { stratospheric ozone } \\
\text { causes greater incidence } \\
\text { of UV }\end{array}$ & Communities & See above & $\begin{array}{l}\mathrm{t} \mathrm{y}^{-1} \mathrm{CFC}- \\
11 \\
\text { equivalent }\end{array}$ \\
\hline & Ecotoxicity & $\begin{array}{l}\text { Freshwater toxicity, } \\
\text { marine toxicity, } \\
\text { terrestrial toxicity from } \\
\text { emissions to air }\end{array}$ & Communities & See above & $\begin{array}{l}\mathrm{t} \mathrm{y}^{-1} \\
1,4-\mathrm{DCB} \\
\text { equivalent }\end{array}$ \\
\hline & Particulates & Degrades materials & Communities & PM10 & $\mathrm{ty}^{-1}$ \\
\hline & $\begin{array}{l}\text { Primary } \\
\text { energy } \\
\text { resource } \\
\text { depletion* }\end{array}$ & $\begin{array}{l}\text { Fewer available } \\
\text { resources to meet future } \\
\text { needs }\end{array}$ & $\begin{array}{l}\text { Future } \\
\text { communities }\end{array}$ & $\begin{array}{l}\text { Total non- renewable energy } \\
\text { consumed }\end{array}$ & $\mathrm{GJ}^{-1}$ \\
\hline \multirow[t]{3}{*}{$\begin{array}{l}\text { Material } \\
\text { Use }\end{array}$} & $\begin{array}{l}\text { Waste to } \\
\text { landfill }\end{array}$ & $\begin{array}{l}\text { Use of land for waste } \\
\text { disposal, emissions }\end{array}$ & Communities & Total waste & $\mathrm{ty}^{-1}$ \\
\hline & $\begin{array}{l}\text { Abiotic } \\
\text { resource } \\
\text { depletion* }\end{array}$ & $\begin{array}{l}\text { Use of non-renewable, } \\
\text { non-recyclable and non- } \\
\text { reusable materials leave } \\
\text { fewer resources } \\
\text { available to meet future } \\
\text { needs }\end{array}$ & $\begin{array}{l}\text { Future } \\
\text { communities }\end{array}$ & Net materials lost & $\begin{array}{l}\mathrm{t} \mathrm{y}^{-1} \\
\text { Antimony } \\
\text { equivalent }\end{array}$ \\
\hline & $\begin{array}{l}\text { Material } \\
\text { processing and } \\
\text { extraction }\end{array}$ & $\begin{array}{l}\text { Release of polluting } \\
\text { substances }\end{array}$ & Communities & $\begin{array}{l}\text { Heavy metals, toxic } \\
\text { chemicals, solvents released }\end{array}$ & $\mathrm{ty}^{-1}$ \\
\hline Water & $\begin{array}{l}\text { Contamination } \\
\text { of water } \\
\text { during vehicle } \\
\text { lifecycle }\end{array}$ & $\begin{array}{l}\text { Treating water involves } \\
\text { an energy cost, dirty } \\
\text { water can spread } \\
\text { contaminants and } \\
\text { bacteria }\end{array}$ & Communities & Quantity of water used & Litres \\
\hline
\end{tabular}

*includes renewable resources used at an unsustainable rate

Table 2. Primary energy (10 ${ }^{6}$ GJ) used by the UK Car fleet, 1995 and 2005.

\begin{tabular}{llll}
\hline & $\mathbf{1 9 9 5}$ & $\mathbf{2 0 0 5}$ & Change \\
\hline Fuel energy consumption & 1230 & 1285 & $4.4 \%$ \\
Embodied emissions in vehicles added to the fleet & 162.8 & 241.8 & $48.5 \%$ \\
Embodied emissions in fuel consumed & 176.4 & 188.3 & $6.7 \%$ \\
Total & 1569.2 & 1715.1 & $9.3 \%$ \\
\hline
\end{tabular}


Final version appeared as: TW. Smith, CJ. Axon, \& RC. Darton (2013). A Methodology for Measuring the Sustainability of Car Transport Systems. Transport Policy, 30, pp. 308-317, DOI:10.1016/ j.tranpol.2013.09.019.

\subsection{Economic Indicators}

Economic impacts take the form of either costs or financial gains, and all five EIRs are affected. We note that many impacts in either the environmental or human / social domains can also be described in monetary terms. For instance, employees are rewarded by the payment of salaries. This has an economic impact, but when considering the issue, namely that employees are able to support themselves and their dependants, it could also be described as a human / social impact, since the issue is largely one of human welfare. Similarly, users incur costs linked to car use, such as maintenance, insurance, operating costs and depreciation, but of the issues raised by those costs, the main one is affordability - an issue related to community welfare. For this study we chose to classify indicators as economic only if they describe issues affecting the economic sustainability of the system itself. These indicators are presented in Table 3.

Table 3. Economic indicators of car transport system sustainability.

\begin{tabular}{|c|c|c|c|c|c|}
\hline $\begin{array}{l}\text { Input / } \\
\text { Output }\end{array}$ & Impact & Issue & EIR & Indicator & Metric \\
\hline Workforce & $\begin{array}{l}\text { Value is added } \\
\text { through the use of } \\
\text { workforce }\end{array}$ & Generates profit & $\begin{array}{l}\text { Capital } \\
\text { Providers }\end{array}$ & $\begin{array}{l}\text { Value added by } \\
\text { automotive industry }\end{array}$ & $£ \mathrm{y}^{-1}$ \\
\hline \multirow[t]{3}{*}{ Mobility } & $\begin{array}{l}\text { Accidents / } \\
\text { Casualties }\end{array}$ & $\begin{array}{l}\text { Financial cost of } \\
\text { accidents to society }\end{array}$ & Communities & $\begin{array}{l}\text { Cost of physical damage, } \\
\text { medical costs, emergency } \\
\text { services }\end{array}$ & $£ \mathrm{y}^{-1}$ \\
\hline & $\begin{array}{l}\text { Mobility is used to } \\
\text { support economic } \\
\text { activity }\end{array}$ & $\begin{array}{l}\text { Speed of mobility - } \\
\text { time is saved } \\
\text { relative to other } \\
\text { modes }\end{array}$ & Users & $\begin{array}{l}\text { Value of time saved per } \\
\mathrm{km}\end{array}$ & $£ \mathrm{~km}^{-1}$ \\
\hline & $\begin{array}{l}\text { Additional revenue } \\
\text { collected by the } \\
\text { government as a } \\
\text { result of car fleet } \\
\text { operation }\end{array}$ & $\begin{array}{l}\text { Government } \\
\text { collects tax revenue } \\
\text { to pay for public } \\
\text { services }\end{array}$ & Communities & $\begin{array}{l}\text { Fuel duty and Vehicle } \\
\text { Excise Duty Collected }\end{array}$ & $£ y^{-1}$ \\
\hline Energy & Air Pollution & $\begin{array}{l}\text { Hazardous to } \\
\text { human health }\end{array}$ & Communities & $\begin{array}{l}\text { Cost to health services of } \\
\text { treatment }\end{array}$ & $£ y^{-1}$ \\
\hline Material Use & $\begin{array}{l}\text { Release of } \\
\text { hazardous } \\
\text { materials }\end{array}$ & $\begin{array}{l}\text { Hazardous to } \\
\text { human health }\end{array}$ & Communities & $\begin{array}{l}\text { Cost to health services of } \\
\text { treatment }\end{array}$ & $£ \mathrm{y}^{-1}$ \\
\hline
\end{tabular}

As an example we consider the value added by automotive industry indicator which captures an economic benefit. The industry providing supply, sale, operation and maintenance of the car fleet needs to remain profitable to ensure the sustainability of the car fleet as a transport system. The results, in terms of gross value added (Table 4) were adapted from the Annual Business Inquiry (ONS, 2007). To ensure a consistent basis for comparison all figures are inflation-adjusted to 2005 pounds sterling, using the Retail Price Index (RPI); the conversion from $£(1995)$ to $£(2005)$ is multiplication by a factor 1.288. Since the data from ONS (2007) relate to the entire motor industry, the values were corrected according to the proportion of private and light goods vehicles operating (sales and maintenance) or produced (manufacturing) in the UK. The growth in sales and maintenance of $25 \%$ is consistent with the $28 \%$ growth in fleet size. Annual production of private and light goods vehicles increased in the period considered from $1.731 \mathrm{~m}$ to $1.768 \mathrm{~m}$ (ONS, 2006), but value added by manufacturing fell, indicating that the sector became less profitable. Additionally the number of new vehicles registered annually rose from $2.024 \mathrm{~m}$ to $2.604 \mathrm{~m}$ (DfT, 2007), which far outstrips the increase in production, since a greater proportion of vehicles was imported to the UK.

Table 4. Approximate gross value added by the UK automotive industry, 1995 and 2005, £million (2005).

\begin{tabular}{llll}
\hline & $\mathbf{1 9 9 5}$ & $\mathbf{2 0 0 5}$ & Change \\
\hline Manufacturing & 11997 & 8906 & $-25.8 \%$ \\
Sales (vehicles, parts, fuel) and maintenance & 16381 & 20563 & $25.5 \%$ \\
Total & 28377 & 29469 & $3.8 \%$ \\
\hline
\end{tabular}


Final version appeared as: TW. Smith, CJ. Axon, \& RC. Darton (2013). A Methodology for Measuring the Sustainability of Car Transport Systems. Transport Policy, 30, pp. 308-317, DOI:10.1016/ j.tranpol.2013.09.019.

\subsection{Human / Social Indicators}

The human / social indicator set (Table 5) comprises a crucial part of the sustainability analysis, because it includes indicators for the major benefit of car transportation to society - the provision of mobility as a service. Evaluating the impact of mobility on sustainability requires care since it raises two separate questions: what is the impact of mobility in general on sustainability, and what is the impact of the mobility provided by the car fleet specifically? Our study does not address the first question, since we exclude from our analysis the benefits and disbenefits of the purposes for which mobility is used. We do not consider whether any particular episode of mobility could have been better avoided, or provided in a different way.

Table 5. Human / Social indicators of car transport system sustainability.

\begin{tabular}{|c|c|c|c|c|c|}
\hline $\begin{array}{l}\text { Input / } \\
\text { Output }\end{array}$ & Impact & Issue & EIR & Indicator & Metric \\
\hline Workforce & Employment & $\begin{array}{l}\text { People can support } \\
\text { themselves }\end{array}$ & Employees & Jobs provided & $\begin{array}{l}\text { Number of } \\
\text { people employed }\end{array}$ \\
\hline \multirow[t]{2}{*}{ Energy } & Air pollution & Hazardous to health & Communities & $\begin{array}{l}\text { Fatalities induced by } \\
\text { car-related air } \\
\text { pollution }\end{array}$ & $\begin{array}{l}\text { Number of deaths } \\
\text { brought forward } \\
\text { per year }\end{array}$ \\
\hline & & & & $\begin{array}{l}\text { Morbidity induced } \\
\text { by car-related air } \\
\text { pollution }\end{array}$ & $\begin{array}{l}\text { Number of } \\
\text { hospital } \\
\text { admissions per } \\
\text { year }\end{array}$ \\
\hline \multirow[t]{5}{*}{ Mobility } & $\begin{array}{l}\text { Mobility is } \\
\text { provided }\end{array}$ & $\begin{array}{l}\text { People are able to } \\
\text { travel }\end{array}$ & Users & $\begin{array}{l}\text { Mobility provided by } \\
\text { car fleet }\end{array}$ & $\begin{array}{l}\text { Passenger-km per } \\
\text { year }\end{array}$ \\
\hline & Service quality & $\begin{array}{l}\text { People are able to } \\
\text { perform trips under } \\
\text { certain conditions }\end{array}$ & Users & $\begin{array}{l}\text { Service quality } \\
\text { indicators (see } 3.3 \text { ) }\end{array}$ & Various \\
\hline & & $\begin{array}{l}\text { The mobility needs of } \\
\text { the community are } \\
\text { met }\end{array}$ & Communities & $\begin{array}{l}\text { Equality of modal } \\
\text { opportunity } \\
\text { indicators (see } 3.3 \text { ) }\end{array}$ & Various \\
\hline & Noise & Hazardous to health & Communities & $\begin{array}{l}\text { Morbidity related to } \\
\text { noise }\end{array}$ & $\begin{array}{l}\text { Number of } \\
\text { medical } \\
\text { interventions per } \\
\text { year }\end{array}$ \\
\hline & $\begin{array}{l}\text { Accidents / } \\
\text { injuries }\end{array}$ & Resulting injury & Communities & $\begin{array}{l}\text { Casualties resulting } \\
\text { from road traffic } \\
\text { collisions }\end{array}$ & $\begin{array}{l}\text { Number of killed } \\
\text { or seriously } \\
\text { injured per year }\end{array}$ \\
\hline
\end{tabular}

In order to capture the impact on sustainability of the mobility provided by the car fleet, both the quality and quantity (in passenger-km) were measured to assess how well the system is performing. This may be termed its 'fitness for purpose', and is an approach consistent with our definition of a sustainable transport system. Quality was considered from the perspective of the users and of the community. The user perspective was captured by user service quality indicators addressing three basic questions - how long the trip will take (including how soon it can be started), under what conditions it will be taken and how safe it will be. The community perspective was captured in the equality of modal opportunity indicators which address the level of access to the mode based on age, socio-economic status and disability, to ascertain whether specific groups suffer exclusion. The sub-indicators used to describe service quality are not detailed in this paper.

The indicator chosen as an illustration in the human/social domain is the number of people in employment indicator. The automotive industry supply chain has a social impact through the jobs it provides, enabling people to support themselves and their dependants. This industry is sizeable, representing approximately $2.75 \%$ of jobs in the UK in 2005. Table 6 shows the average employment during each year, as well as the costs (to businesses) per employee, which cover gross wages and salaries (including redundancy and severance payments) and social security costs. The data were taken from the Annual Business Inquiry 
Final version appeared as: TW. Smith, CJ. Axon, \& RC. Darton (2013). A Methodology for Measuring the Sustainability of Car Transport Systems. Transport Policy, 30, pp. 308-317, DOI:10.1016/ j.tranpol.2013.09.019.

published by the Office for National Statistics (ONS, 2007). The data covered retail, manufacture and maintenance of all motor vehicles and fuel indiscriminately so a correction was made to estimate the contribution of private and light goods vehicles. The correction was broadly made according to the proportion of private and light goods vehicles produced by UK manufacturers. The insurance industry also contributes to employment, although no appropriate data were found to describe this impact. Overall there was a drop in employment over the period. The biggest decline was in manufacturing, but there was also a small reduction in retail (vehicles, parts and fuel) and maintenance, which needs explanation. The sector comprises several subcomponents (retail of vehicles, retail of parts, retail of fuel and maintenance; data from ONS 2007, not disaggregated in Table 6). Of these, only maintenance saw an increase in employment, but that increase was considerable, almost $40 \%$. This is related to the increase in fleet size of $\sim 28 \%$. However, it is not clear why other employment declined, despite increases in fuel consumption and annual new car registrations. The costs per employee (gross wages and salaries) also increased significantly over the period and as these figures have been adjusted for inflation, it seems that overall both the quality of jobs and labour productivity improved during the period.

Table 6. Employment in the UK automotive industry. Costs in $£(2005)$.

\begin{tabular}{lllllll}
\hline & $\begin{array}{l}\mathbf{1 9 9 5} \\
\text { Employment } \\
\text { (thousands) }\end{array}$ & $\begin{array}{l}\text { Costs(£)/ } \\
\text { Employee }\end{array}$ & $\begin{array}{l}\mathbf{2 0 0 5} \\
\begin{array}{l}\text { Employment } \\
\text { (thousands) }\end{array}\end{array}$ & $\begin{array}{l}\text { Costs(£)/ } \\
\text { Employee }\end{array}$ & $\begin{array}{l}\text { Change } \\
\text { Employment }\end{array}$ & $\begin{array}{l}\text { Costs / } \\
\text { Employee }\end{array}$ \\
\hline Manufacturing & $282^{*}$ & 25954 & 205 & 31617 & $27.3 \%$ & $21.8 \%$ \\
$\begin{array}{l}\text { Sales (vehicles, } \\
\text { parts, fuel) and } \\
\text { maintenance }\end{array}$ & $562 *$ & 11965 & 560 & 17383 & $-0.4 \%$ & $45.3 \%$ \\
Total & $843 *$ & 16640 & 765 & 21195 & $-9.3 \%$ & $27.4 \%$ \\
\hline
\end{tabular}

*Denotes extrapolated data

\section{Discussion}

This paper addresses two questions: first whether the Process Analysis Method is an appropriate tool for assessing the sustainability of a distributed service system, and second, what particular indicators of transportation sustainability emerge from this analysis.

\subsection{PAM Performance}

The methodology of the PAM highlighted several aspects of measuring the sustainability of a distributed system providing a service. In such a system, impacts on the stores of value, by which we measure the change in sustainability, result from the decisions of a wide range of stakeholders. For the UK car fleet these include regulatory bodies, Government, businesses involved in the manufacture, sale, maintenance and disposal of vehicles, and the users themselves. Frequently the decisions and actions of stakeholders influence each other, introducing feedback loops. For example, several million individuals in the UK make decisions every year about the acquisition or disposal of a car. These decisions are influenced by factors such as regulation and taxation, product specification and availability. These factors are in principle determined by other stakeholders (Government, manufacturers), but they will be influenced by the behaviour of the user community as a whole, as stakeholders seek to raise taxation revenue, reduce congestion, ensure pedestrian safety, run a profitable business and so on. An advantage of the PAM methodology is that no model of these complex interactions is required - sustainability is assessed only according to the impacts observed and the issues identified. Further, because there is no detailed model, the Internal Impact Generators can be aggregated for convenience e.g. user decisions. The identification of IIGs then serves more as a means of checking the relevance of an indicator than as a contribution to modeling causal relationships. If an impact cannot be traced to one or more IIGs then the impact cannot be influenced, and is not appropriate in assessing the system sustainability. The PAM has some similarities with the Pressure-State-Response (PSR) approach, which also considers cause and impact (OECD, 1993). However PSR and its derivatives involve 
Final version appeared as: TW. Smith, CJ. Axon, \& RC. Darton (2013). A Methodology for Measuring the Sustainability of Car Transport Systems. Transport Policy, 30, pp. 308-317, DOI:10.1016/ j.tranpol.2013.09.019.

the modeling of this causal relationship and thus the full understanding of its complexity, whereas the PAM observes the dependence and does not require a complex model (Chee Tahir and Darton, 2010).

The PAM considers an impact as positive or negative in terms of the issues it creates, and there may be more than one. So, in the case of fuel duty for example, provision of revenue to government is positive (Table 3, Issue is Government collects tax revenue to pay for public services), but effect on the community is negative, by affecting affordability where it features as part of the equality of modal opportunity indicator (Table 5, Issue is The mobility needs of the community are met). Thus we have two separate indicators related to one process (payment of fuel duty). This is not double-counting as long as distinct issues are identified, and in this example the distinction is quite clear because we have one positive and one negative effect, though this will not always be so. In this case it may be envisaged that a trade-off in benefit and disbenefit of the different issues is possible, perhaps indicating that an optimum or target could be attained. In any analysis, many such possible trade-offs may be encountered in which various benefits and disbenefits may be balanced. The PAM itself makes no decision on trade-offs, which must be determined in a separate exercise, perhaps as policy formulation specific to the particular national context, typically involving stakeholder input.

Double-counting should be avoided in sustainability assessment. With the PAM double-counting would arise if the same issue were assigned two or more indicators. For example, in considering the economic value of fast mobility in saving time, it would not be correct to include both the average speed of car travel and the value of time saved. In this case the value of time saved (Table 3) is a direct measure of the issue, and is what we use. Sometimes there may be an appearance of double-counting when differing impacts are related. For example, with respect to road accidents, we have chosen to include a metric both for the financial cost of accidents to society (Table 3) and for the number of killed or seriously injured (Table 5). This is based on the consideration that whilst the economic store of value is depleted by the financial cost of an accident, there is an additional and quite separate impact in the pain and suffering caused within the community and that this should be shown within the human/social domain. A second instance where doublecounting might perhaps be suspected is where sub-indicators are used to illustrate different aspects of an issue, as shown in Tables 2, 4 and 6. However, as long as they characterize different features, they remain distinct sub-indicators and do not count the same thing twice.

The users form a unique stakeholder group, as the impacts they generate are the emergent result of many individual decisions. Car users are shown by the analysis to have dual roles, both as individual makers of decisions and as beneficiaries / sufferers of the impacts resulting from communal choice. This is fundamental to understanding why it has proved hard to bring about sustainability in the car fleet. Improvements, which could result from behavioural change, require change by millions of independent agents who have both electoral and purchasing power. Through purchasing and driving cars, users create issues (such as pollution, congestion) that directly affect the experience of the user community, characterized by the service quality indicators. This in turn affects subsequent decisions by individual users on purchasing and use, thus closing a feedback loop.

It is worth noting that sustainability disbenefits are often inequitably shared - health effects of air pollution, climate change caused by car emissions, road congestion and noise, are examples of impacts that will be suffered by many who do not benefit from the mobility that the car fleet provides.

It is important when applying the PAM that indicators should not be included to describe the causal chain creating the issues (in this PAM differs from PSR and similar methodologies which include descriptors of the system). For example, if a particular car is driven further, its $\mathrm{CO}_{2}$ emissions will increase. But total vehicle-kilometers is not a safe indicator of $\mathrm{CO}_{2}$ emissions of the car fleet, since it is influenced by other factors such as engine efficiency. In this example, if the issue is $\mathrm{CO}_{2}$-driven climate change, we should adopt an indicator for that and not for something else. In this case the data are readily available for car fleet $\mathrm{CO}_{2}$ emissions, but this may not be the case for every impact selected. The use of surrogate indicators, which indicate how a (closely) related variable changes, needs great care. In any case the PAM requires that we identify and quantify the sustainability consequences of impacts, not indicators that simply describe the system.

In this study, there was no stakeholder involvement in the analysis. The formal PAM methodology (Chee Tahir and Darton, 2010) includes a step of verification / modification in which stakeholder consultation is usually appropriate. This is useful for checking that all the issues are well understood, as well as determining the spread of weightings which need to be considered when forming composite indicators. 
Final version appeared as: TW. Smith, CJ. Axon, \& RC. Darton (2013). A Methodology for Measuring the Sustainability of Car Transport Systems. Transport Policy, 30, pp. 308-317, DOI:10.1016/ j.tranpol.2013.09.019.

A common problem in sustainability assessment is the availability of data. Whilst this problem is diminishing as awareness of the issues surrounding sustainability grows and more data are released (at least with respect to car transportation), the analyst can encounter indicators for which there are no adequate data to yield metrics. It is noteworthy that despite the huge importance of the UK car fleet to its users and to the economy, and its important sustainability impacts, data required for a proper assessment has to be gleaned from so many disparate sources. Naturally the availability of data for a particular indicator does not mean that indicator ought to be included. The selection of indicators should always reflect the issues that were identified.

\subsection{Indicator Set}

Applying the PAM to a car fleet generated the comprehensive set of indicators shown in Tables 1, 3 and 5. These indicators are related to the inputs and outputs of the transport system identified in Figure 2, and are consistent with the high-level goals expressed in the definition of sustainability. These indicators characterize the issues identified. However they can mostly be disaggregated into further sub-indicators to present a fuller description of a particular aspect. For example the jobs provided indicator (Table 5) is disaggregated in Table 6 to show jobs in Manufacturing and Sales/Maintenance; alternative disaggregation would be possible. We note that, although our study is based on the UK car fleet, the indicator set turns out not to be specific to this single country; we suggest that a similar set would result from the study of any country where the car has a similar socio-economic role.

The environmental indicators focus on the consequences of resource use. The main issues are resource depletion and environmental degradation, two aspects common to many engineered systems. The indicators relating to the use of hydrocarbon fuel highlight the well-known problems of $\mathrm{CO}_{2}$ emissions and fuel security. The economic indicators reflect both the costs and contributions to the economy of operating the car fleet. Costs include those associated with accidents and health issues, and economic contributions include the value of a large and profitable manufacturing and service sector. Employment in this industrial sector is one benefit within the human/social domain, where the principal benefit is the provision of good quality mobility to the car users. Here indicators are concerned with two main issues: the quantity and quality of the mobility provided (how well it meets transport needs), and the impacts of car fleet operation on the community, in particular in terms of health and safety (Smith, T.W. et al., 2013).

The method requires a clear definition of a sustainable transport system. Our definition is consistent with the Brundtland definition of sustainability, and makes an explicit statement of the service requirements and the limitations on resource consumption. Following Brundtland, meeting present needs through service (mobility) provision is considered together with both present and future impacts. The result is a set of indicators representing the declared definition of sustainability. This approach differs in principle from those which derive indicators attuned to national or regional transport policy (e.g. Henning et al. 2011; Ramani et al., 2011; Jeon et al. 2013). These place an extra "policy filter" between the definition of sustainability and the indicator set, leading to norms and targets, and concepts such as "excess" benefits or disbenefits which describe deviation from policy expectations. The formal PAM methodology does not involve targets, which must be considered separately if necessary. Some less robust methods generate indicators by focusing on just one aspect, or on several aspects but with no clear methodology for selection. We have to use judgement when selecting indicators, in deciding which impacts are sufficiently important to warrant inclusion, and it may be argued that this is an arbitrary choice. However the methodology is transparent, and the indicator set should always be screened against the sustainability goals of the analysis with stakeholder input where appropriate.

In creating the indicator set, our underlying assumption is that mobility itself is beneficial. This view is appropriate in our research, but would be less so for a transport study with wider objectives. For example, Gudmundsson and Höjer (1996) note that they "are not convinced that mobility is an undeniable good, and not a condition compulsively forced upon the individual by social and physical structures", suggesting that "if access can be provided in some other fashion than by the physical movement of people and goods, this may be the most promising option in the longer term." Banister $(2008,2011)$ argues that efforts towards sustainable mobility should focus on the reduction of demand, both in terms of distance and number of trips. Banister links the issue to urban form, where the structure of the built environment affects the demand for transport. Similarly, Lucas et al. (2007) and Walker et al. (2006) focus more on access to jobs, goods and services than on mobility. These different ways of assessing transport systems address the fundamental question of how access to goods and services could be most sustainably provided. Our objective was more 
Final version appeared as: TW. Smith, CJ. Axon, \& RC. Darton (2013). A Methodology for Measuring the Sustainability of Car Transport Systems. Transport Policy, 30, pp. 308-317, DOI:10.1016/ j.tranpol.2013.09.019.

limited, predicated on the existence of a car fleet, to see how its sustainability is changing. It is surely necessary to address both questions, since transport policymaking requires a good understanding of the sustainability of the car fleet. It could be considered a question of boundaries - this study focuses purely on the provision of mobility, whereas the 'accessibility' approach includes the larger question of the uses to which it is put. A first step in extending our study in the direction of accessibility would be to include infrastructure within the system boundary. This would begin to capture impacts linked to urban form, and competition of car transport with other modes.

\section{Conclusions}

We investigated the suitability of the Process Analysis Method (PAM) for measuring the sustainability of a car fleet delivering mobility. The PAM identifies sustainability impacts resulting from system processes, characterising the issues (consequences) arising from these impacts with indicators. It is transparent and systematic, and helps the user create an indicator set which is comprehensive, whilst avoiding doublecounting. Particular issues can be further described with sub-indicators.

Associating indicators with defined issues linked back to system processes reveals trade-offs that might be possible in balancing benefits and disbenefits, though the PAM itself does not incorporate tradeoffs, which must be the result of a separate policy discussion specific to the particular national context.

The environmental indicators produced by the PAM described resource depletion and environmental degradation issues. The economic indicators included financial gains and losses such as the costs of health impacts and the value added by the automotive industry. Indicators within the human/social domain included the major benefits of mobility, to which service quality makes a contribution warranting further investigation.

A definition of a sustainable transport system was developed, consistent with the basic definition of Brundtland, but specifying the requirements in sufficient detail for the analysis. The indicator set is thus likely to be widely applicable and is also manageable in size - both are important criteria for adoption by transport and sustainability practitioners. The indicator set was developed for the UK, but it should be applicable to any country where the car serves in a similar socio-economic role. In working towards a more sustainable car fleet, notice should be taken of the full range of sustainability impacts identified by the methodology.

\section{References}

AEA, 2010. National Atmospheric Emissions Inventory. [online] Available at: 〈http://www.naei.org.uk> [Accessed June 2010].

Akinyemi, E., 2002. Managing Transportation Infrastructure for Sustainable Development. Computer-Aided Civil and Infrastructure Engineering, 17, pp. 148-161.

Banister, D., 2008. The sustainable mobility paradigm. Transport Policy, 15(2), pp. 73-80.

Banister, D., 2011. The trilogy of distance, speed and time. Journal of Transport Geography, 19(4), pp. 950959.

Baumann, H. and Tillman, A-M. 2004. The Hitch Hiker's Guide to LCA: an orientation in life cycle assessment methodology and application. Lund, Sweden: Studentlitteratur.

Black, J.A., 2002. Sustainable urban transportation: Performance indicators and some analytical approaches. Journal of Urban Planning and Development, 128(4), pp. 184-209.

Bojkovic, N., Anic, I., Pejcic-Tarle, S., 2010. One solution for cross-country transport-sustainability evaluation using a modified ELECTRE method. Ecological Economics, 69, pp. 1176-1186.

Brundtland, G. Ed., Our Common Future: The World Commission on Environment and Development, Oxford University Press, Oxford, 1987.

Castillo, H., Pitfield, D.E., 2010. ELASTIC - A methodological framework for identifying and selecting sustainable transport indicators. Transportation Research Part D, 15, pp. 179-188.

Chee Tahir, A. and Darton, R. C., 2010. The Process Analysis Method of selecting indicators to quantify the sustainability performance of a business operation. J. Clean Prod, 18 (16-17), pp. 1598-1607.

Dalal-Clayton, B. and Bass, S., 2002. Sustainable Development Strategies: a Resource Book. London: Earthscan.

DfT, 2007. Transport Statistics Great Britain: 2007, Department for Transport, London, UK.

DfT, 2012. Transport Statistics Great Britain: 2012, Department for Transport, London, UK. 
Final version appeared as: TW. Smith, CJ. Axon, \& RC. Darton (2013). A Methodology for Measuring the Sustainability of Car Transport Systems. Transport Policy, 30, pp. 308-317, DOI:10.1016/ j.tranpol.2013.09.019.

Edwards, R.,Larive, J.-F., Mahieu, V., Rouveirolles, P., 2007. Well-To-Wheels Analysis of Future Automotive Fuels and Powertrains in the European Context, Tech. Rep. 2c, (CONCAWE) European Commission Joint Research Centre.

Elkington, J., 1998. Cannibals with Forks: The triple bottom line of 21st century business. New Society Publishers: Gabriola Island, BC Canada

European Commission, 2001. A sustainable Europe for a better world: A European Union strategy for sustainable development (Commission's proposal to the Gothenburg European Council). [online] Available at:

http://eur-lex.europa.eu/LexUriServ/LexUriServ.do?uri=CELEX:52001DC0264:EN:HTML [Accessed January 2012]

European Commission, 2006. Implementing the Community Strategy to Reduce CO2 Emissions from Cars: Sixth annual Communication on the effectiveness of the strategy, Brussels, Belgium.

Fedra, K., 2011. Sustainable Urban Transportation: A Model-Based Approach. Cybernetics and Systems, 35(5-6), pp. 455-485.

Grimes-Casey, H.G., Keoleian, G. A and Willcox, B., 2009. Carbon Emission Targets for Driving Sustainable Mobility with US Light-Duty Vehicles. Environmental Science and Technology, 43(3), pp. 585-590.

Gudmundsson, H. and Höjer, M., 1996. Sustainable development principles and their implications for transport. Ecological Economics, 19, pp. 269-282.

Guinée, J.B., Gorrée, M., Heijungs, R., Huppes, G., Kleijn, R., Koning, A. de, ... Huijbregts, M.A.J. 2002 Handbook on life cycle assessment. Operational guide to the ISO standards. Kluwer Academic Publishers, Dordrecht

Haghshenas, H., Vaziri, M., 2012. Urban sustainable transportation indicators for global comparison. Ecological Indicators, 15, pp. 115-121.

Henning, T.F.P., Muruvan, S., Feng, W.A., Dunn, R.C., 2011. The development of a benchmarking tool for monitoring progress towards sustainable transportation in New Zealand. Transport Policy, 18, pp. 480-488.

IChemE, 2004. Sustainable Development Progress Metrics Recommended for use in the Process Industries. Rugby, U.K: Institution of Chemical Engineers.

Jeon, C.M., Amekudzi, A.A. and Guensler, R.L. 2013. Sustainability assessment at the transportation planning level: Performance measures and indexes. Transport Policy, 25, pp. 10-21.

Joumard, R., Nicolas, J.-P., 2010. Transport project assessment methodology within the framework of sustainable development. Ecological Indicators, 10, pp. 136-142.

Kennedy, C.A., 2002. A comparison of the sustainability of public and private transportation systems: Study of the Greater Toronto Area. Transportation, 29(4), pp. 459-493.

Lucas, K., Marsden, G., Brooks, M. and Kimble, M., 2007. Assessment of Capabilities for Examining LongTerm Social Sustainability of Transport and Land use Strategies. Transportation Research Record: Journal of the Transportation Research Board, 2013, pp. 30-37.

Marsden, G., Kimble, M., Nellthorp, J., Kelly, C., 2010. Sustainability Assessment: The Definition Deficit. International Journal of Sustainable Transportation, 4, pp. 189-211.

Miranda, H.F., Rodrigues da Silva, A.N., 2012. Benchmarking sustainable urban mobility: The case of Curitiba, Brazil. Transport Policy, 21, pp. 141-151.

Nicolas, J.-P., Pochet, P. and Poimboeuf, H., 2003. Towards sustainable mobility indicators: application to the Lyons conurbation. Transport Policy, 10(3), pp. 197-208.

OECD, 1993. OECD core set of indicators for environmental performance reviews, OECD Environment Monographs No. 83. OECD. Paris.

ONS, 2006. Motor Vehicle Production Inquiry: Business Monitor PM34.10, Norwich: HMSO. [online] Available at:< http://www.ons.gov.uk/ons/publications/re-reference- tables.html?edition=tcm\%3A7754735> [Accessed November 2011].

ONS, 2007. Annual Business Inquiry, Division 50. [online] Available at <http://www.ons.gov.uk/ons/publications/re-reference-tables.html?edition=tcm\%3A77-235505>, [Accessed November 2011].

Ramani, T. L., Zietsman, J., Gudmundsson, H., Hall, R.P. and Marsden, G., 2011 Framework for Sustainability Assessment by Transportation Agencies Transportation Research Record No 2242 Pages: 9-18 DOI: $10.3141 / 2242-02$ 
Final version appeared as: TW. Smith, CJ. Axon, \& RC. Darton (2013). A Methodology for Measuring the Sustainability of Car Transport Systems. Transport Policy, 30, pp. 308-317, DOI:10.1016/ j.tranpol.2013.09.019.

Rassafi, A.A., 2005. Sustainable transport indicators: Definition and integration. International Journal of Environmental Science and Technology, 2(1), pp. 83-96.

Rennings, K and Wiggering, H., 1997. Steps towards indicators of sustainable developments: linking economic and ecological concepts, Ecological Economics, 20, pp. 25-36.

Richardson, B.C., 2005. Sustainable transport: analysis frameworks. Journal of Transport Geography, 13(1), pp. 29-39.

Roth, A. and Kåberger, T., 2002, Making transport systems sustainable. Journal of Cleaner Production, 10(4), pp. 361-371.

Shiau, T.-A., Jhang, J.-S., 2010. An integration model of DEA and RST for measuring transport sustainability. International Journal of Sustainable Development and World Ecology, 17(1), pp. 7683.

Smith, T.W., Axon, C.J. and Darton, R.C., 2013 The impact on human health of car-related air pollution in the UK, 1995-2005. Atmos Env.77, pp. 260-266.

Too, L., Earl, G., 2010. Public Transport Service Quality and Sustainable Development: a Community Stakeholder Perspective. Sustainable Development, 18, pp. 51-61.

Walker, W. E., Adnan Rahman, S., van Grol, R., Klautzer, L., 2006. Operationalizing the Concept of Sustainable Transport and Mobility. Environmental Practice, 8, pp. 24-48.

WBCSD, 2004. Mobility 2030: Meeting the challenges to sustainability. World Business Council for Sustainable Development, Geneva, Switzerland. Available at: <www.wbcsd.org/web/publications/mobility/overview.pdf> [Accessed January 2012].

Yigitcanlar, T. and Dur, F., 2010. Developing a Sustainability Assessment Model: The Sustainable Infrastructure, Land-Use, Environment and Transport Model. Sustainability, 2, pp. 321-340.

Zachariadis, T., 2005. Assessing policies towards sustainable transport in Europe: an integrated model. Energy Policy, 33(12), pp. 1509-1525. 